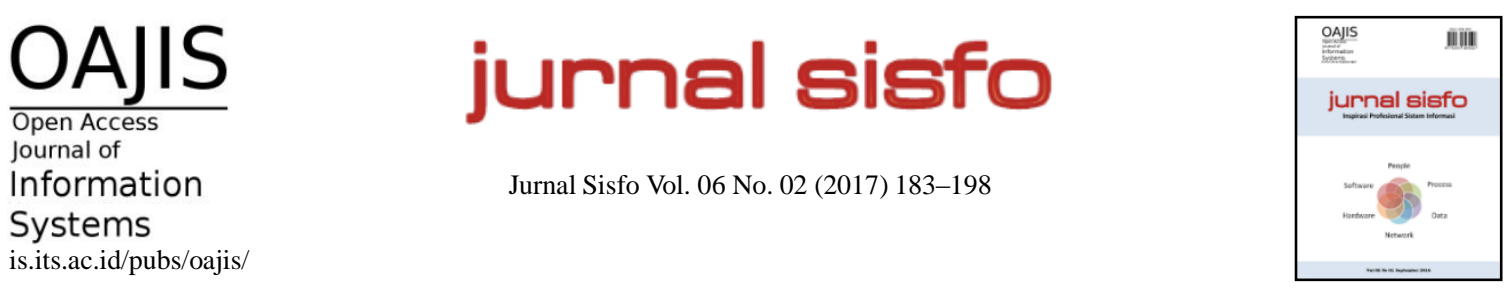

\title{
Studi Faktor Penilaian Plagiat Menggunakan Analytical Hierarchy Process: Sebuah Studi Kasus Kualitatif
}

\author{
Hilyah Magdalena*, Hadi Santoso \\ Program Studi Sistem Informasi, STMIK Atma Luhur
}

\begin{abstract}
Plagiarism is a fraudulent behavior that takes the results of scientific work of others and acknowledge it as the work itself. There are many categories: scope, media, reason, and form of plagiarism. The higher education institutions are one of the institutions that are prone the plagiarism behavior. This study is designed to assemble the factors that can be used as a basis for assessing whether a scientific paper is the result of plagiarism or not, especially for the scope of STMIK Atma Luhur campus. This study involves a multi-criteria and multi alternative. This situation requires research methods capable of considering the qualitative and quantitative aspects. Under these conditions, this research uses Analytical Hierarchy Process, as AHP ables to apply complex mathematical approach intelligently based on a qualitative basis. Data processing results show that the most important factor to be considered in assessing plagiarism is a weighting factor Actors by $17.9 \%$; the second most important factor is the Scope of Plagiarism by weight of 17\%; and the third most important factor is the Category of Plagiarism. While the results of scientific work of the most widely targeted for plagiarism is the article with a weight of $34.1 \%$.
\end{abstract}

Keywords: Plagiarism, Analytical Hierarchy Process, STMIK Atma Luhur

\begin{abstract}
Abstrak
Plagiat adalah perilaku curang yang mengambil hasil karya ilmiah orang lain dan mengakuinya sebagai karya sendiri dengan berbagai kategori, ruang lingkup, media, alasan, dan bentuk plagiat di Perguruan Tinggi. Penelitian ini adalah studi kasus kualitatif untuk menyusun faktor-faktor penilaian karya ilmiah adalah hasil plagiat atau bukan, khususnya untuk ruang lingkup kampus STMIK Atma Luhur. Penelitian ini melibatkan banyak kriteria dan banyak alternatif. Keadaan ini membutuhkan metode penelitian yang mampu mempertimbangkan aspek kualitatif dan kuantitatif. Hal itulah yang mendasari peneliti menggunakan metode Analytical Hierarchy Process, karena AHP mampu menerapkan pendekatan matematis kompleks secara cerdas namun berdasarkan pendekatan kualitatif. Hasil Pengolahan data menunjukkan bahwa faktor terpenting untuk dicermati dalam menilai plagiat adalah faktor Pelaku dengan bobot 17,9\%, faktor terpenting kedua adalah Ruang Lingkup Plagiarisme dengan bobot 17\%, dan faktor terpenting ketiga adalah Kategori plagiarisme. Sedangkan hasil karya ilmiah yang paling banyak dijadikan sasaran plagiat adalah Artikel dengan bobot $34,1 \%$.
\end{abstract}

Kata kunci: Plagiarisme, Analytical Hierarchy Process, STMIK Atma Luhur

(C) 2017 Jurnal SISFO.

Histori Artikel : Disubmit 23 Desember 2016; Diterima 18 Januari 2017; Tersedia online 24 Januari 2017

${ }^{*}$ Corresponding Author

Email address: hilyah@atmaluhur.ac.id (Hilyah Magdalena) 


\section{Pendahuluan}

Perguruan tinggi di Indonesia berdiri diatas tiga pilar utamanya yaitu Pendidikan, Penelitian, dan Pengabdian kepada Masyarakat. Tiga pilar ini menurut UU No.12 Tahun 2012 [1] disebut Tri Dharma Perguruan Tinggi. Berdasarkan UU tersebut, maka seorang dosen wajib menjalankan tugas dan fungsinya sebagai pendidik, peneliti, dan abdi masyarakat dalam bidang keilmuan. Dalam menjalankan tugas dan fungsinya tersebut, terjadi perubahan dengan meningkatnya porsi penelitian dosen yang naik cukup signifikan. Hal ini mengingat masih kurangnya hasil penelitian dan penelitian yang dipublikasikan oleh dosen atau peneliti. Masalah yang muncul kemudian adalah tidak semua dosen mempunyai waktu dan kemampuan untuk membuat penelitian. Sudah menjadi rahasia umum, jika porsi terbesar waktu dosen adalah untuk melakukan pendidikan dan pengajaran dengan tatap muka di kelas. Kendala lain juga muncul adalah kurangnya sarana untuk melakukan penelitian. Selain dosen, mahasiswa juga harus melakukan penelitian di akhir masa studinya. Bagi mahasiswa membuat penelitian diakhir masa studi adalah syarat untuk kelulusan. Sehingga mahasiswa juga harus bekerja keras untuk melalui semua tahap - tahap penelitian untuk menghasilkan nilai yang terbaik.

Di Perguruan Tinggi sudah sejak lama ada kecenderungan hasil penelitian mengandung porsi plagiat cukup tinggi. Pemerintah dan pihak kampus umumnya menyadari hal ini, maka hadirlah banyak peraturan dan undang - undang yang khusus mengatur cara mencegah dan menanggulangi plagiat di perguruan tinggi. Hal ini terlihat dengan dikeluarkannya Undang Undang No.17 Tahun 2010 tentang pencegahan dan penanggulangan palgiat di Perguruan Tinggi [2]. Namun plagiat tidak mudah untuk dibasmi. Salah satu cara mengurangi perilaku plagiat adalah dengan mewajibkan mahasiswa, dosen, maupun tenaga kependidikan untuk mempublikasikan hasil penelitiannya. Tujuan publikasi adalah untuk menyebarluaskan hasil penelitian dan juga menjadi indikator keaslian penelitian. Jika penelitian yang dihasilkan oleh seorang mahasiswa atau dosen adalah hasil plagiat, maka pasti yang bersangkutan akan mendapat protes bahkan tuntutan hukum dari peneliti aslinya. Untuk melandasi kewajiban publikasi hasil penelitian bagi lulusan Sarjana, Magister, dan Doktor terhitung sejak 12 Januari 2012. Surat edaran tersebut DIKTI tersebut adalah surat dirjen dikti no. 152/e/t/2012 [3]. Perilaku plagiat telah banyak mencoreng nama baik mahasiswa, dosen, dan perguruan tinggi. Beberapa kasus bahkan menjadi sorotan cukup tajam dari masyarakat luas karena dilakukan oleh seseorang yang mempunyai pangkat dan kedudukan cukup tinggi. Banyaknya kasus plagiat di perguruan tinggi di Indonesia terbukti dengan mencuatnya beberapa kasus besar yang cukup mengagetkan seperti yang dikutip dari Koran Sindo, Selasa (25/2/2014), berikut beberapa kasus plagiarisme di lingkungan kampus : Pada 25 Maret 2000, Universitas Gadjah Mada (UGM) mencabut gelar doctor Ipong S Azhar. Disertasinya yang diterbitkan menjadi buku berjudul "Radikalisme Petani Masa Order Baru: Kasus Sengketa Tanah Jenggawah" pada pertengahan 1999 ternyata menjiplak karya peneliti LIPI bernama Mochammad Nurhasim. Selanjutnya pada 8 Februari 2010, Prof Anak Agung Banyu Perwita, dosen Jurusan Hubungan Internasional Universitas Katolik Parahyangan mengundurkan diri dari jabatannya sebagai dosen akibat skandal plagiarisme. Artikelnya di sebuah surat kabar harian Jakarta post (16/11/2009) berjudul "RI as a New Middle Power?" menjiplak karya tulis ilmiah milik Carl Ungerer, "The Middle Power Concept in Australian Foregin Policy" di Australian Journal of Politics and Histroy : Volume 53 Number 4, pada 2007. Masih pada tahun 2010, tepatnya pada 15 April 2010, reputasi Institut Teknologi Bandung (ITB) tercoreng setelah alumninya, Dr. M. Zuliansyah, melakukan plagiarisme. Makalahnya berjudul "3D Topological Relations for 3D Spatial Analysis" terbukti menjiplak makalah berjudul "On 3D Topological Relationship" karya Siyka Zlatanova yang diterbitkan di jurnal IEEE. Kemudian pada tahun 2011, tepatnya pada 24 Agustus 2011 Kementerian Pendidikan dan Kebudayaan (Kemendikbud) menyatakan Guru Besar Universitas Riau (UNRI) Prof Dr. Isjoni Ishaq Msi terbukti melakukan plagiarisme dalam membuat buku judul "Sejarah Maritim". Buku dimaksud merupakan jiplakan dari Buku Budaya Bahari Karya Mayor Jenderal (Marinir) Joko Pramono pada 2005. Pada tahun 2012, pada 17 April 2012, Universitas Lampung (Unila) memastikan telah memecat calon guru besar FKIP berinisial BS yang diduga melakukan plagiat karya ilmiah keputusan itu diambil setelah tim verifikasi berhasil membuktikan pelanggaran kode etik dosen tersebut. Masih di tahun 2012, 4 Maret 2012, Senat akademik UPI Bandung 
menjatuhkan sanksi penurunan jabatan dan golongan bagi tiga calon guru besar karena terbukti melakukan plagiarisme. Mereka adalah Dr. Cecep Darmawan (Direktur Kemahasiswaan UPI \& Rektor Universitas Subang), Dr. B Lena Nuryanti (Dosen FPIPS UPI), dan Dr. Ayi Suherman (Dosen UPI Kampus Sumedang). Kemudian pada 7 Februari 2014, Yayasan Perguruan Tinggi Kristen Maranatha (YPTKM) memberhentikan sementara Rektor Universitas Kristen Maranatha (UKM) Dr. dr. Felix Kasim MKes. Pemberhentian itu berkaitan dengan proses penyelidikan dugaan plagiarisme yang dilakukan Felix. Felix Kasim diduga telah melakukan plagiarisme terhadap sejumlah karya ilmiah mahasiswanya. Tak berselang lama, yaitu pada 17 Februari 2014 Dirjen Penyelenggaraan Haji dan Umroh Kemenag Anggito Abimanyu mengundurkan diri dari jabatan dosen di UGM. Sikap ksatria itu dilakukan menyusul tuduhan plagiarisme yang dilakukan Anggito terhadap artikelnya "Gagasan Asuransi Becana" yang terbit di harian Kompas, 10 Februari 20174. Tulisan ini memiliki kesamaan dengan artikel Hotbonar Sinaga dan Munawar Kasan berjudul "Menggagas Asuransi Becana". Selanjutnya masih ditahun 2014 juga terjadi tindak plagiarisme oleh Wakil Rektor II Unhas Dr. dr. Wardihan A Sinrang MS diduga menerbitkan hasil penelitian orang lain dengan judul "Effect of Isolated Active Compound (BV103) of Boehmeria Virgata (Forst) Guil Leaves on Anti- Proliferation in Human Cervix Hela Cells Through Activation of Caspase 3 dan p53 Protein" yang dimuat di jurnal Tropical Medicine \& Surgery (TMS), Vol.1, Issue 3, 2013. artikel itu memiliki kesamaan/ kemiripan dengan judul sama yang di muat di majalah Farmasi dan Farmakologi, Vol 16, No 3 November 2012, Halaman 115-120 [4].

Mengingat besarnya kerugian yang ditimbulkan oleh perilaku plagiat, maka ada baiknya mengkaji ulang secara mendalam dan spesifik untuk masing - masing perguruan tinggi. Sebagai contoh kampus - kampus yang ada di Bangka Belitung, tentu beda alasan dan kecenderungan plagiatnya. Pada bulan Agustus 2016 yang lalu beberapa dosen Universitas Bangka Belitung (UBB) terbukti plagiat di jurnal internal kampus. Plagiat jurnal dilakukan oleh beberapa dosen UBB tersebut untuk kepentingan kenaikan jenjang jabatan akademik (JJA). Kasus ini menjadi perhatian masyarakat Bangka Belitung dan jadi tajuk utama koran harian Babel Pos tanggal 25 Agustus 2016. Menurut berita di harian Babel Pos, keempat dosen yang terbukti plagiat diberi sanksi berupa penghentian kenaikan pangkat, dilarang membimbing mahasiswa selama 2 semester, dan meminta maaf kepada pemilik jurnal asli. Tidak disebutkan pemilik asli jurnal tersebut apakah mahasiswa atau dosen lain.

Masalah plagiat juga terjadi di kampus STMIK Atma Luhur yang beralamat di Kota Pangkalpinang Provinsi Kepulauan Bangka Belitung. Plagiat dilakukan oleh mahasiswa yang mengambil judul dan isi skripsi mahasiswa lain yang sudah lulus. Untuk memberikan efek jera, pihak kampus membatalkan nilai mahasiswa yang bersangkutan dan mewajibkan pelaku untuk membuat skripsi ulang. Seiring dengan meningkatnya tuntutan membuat penelitian bagi dosen, maka pelaku plagiat bukan hanya mahasiswa, namun juga dosen. Pernah terjadi kasus yang mirip dengan kasus plagiat di UBB, namun tidak sampai menjadi konsumsi publik seperti kasus di UBB. Pihak kampus segera mengambil tindakan dengan menjatuhkan sanksi akademik kepada pelaku berupa, teguran dan penuruan pangkat/jabatan. Dengan adanya beberapa kejadian plagiat, maka penulis berinisiatif untuk membuat penelitian yang bertujuan untuk mengkaji faktor - faktor apa saja yang menjadi penilaian sebuah karya ilmiah dapat disebut plagiat khusus untuk di lingkungan STMIK Atma Luhur. Penelitian ini dilakukan terbatas untuk lingkungan STMIK Atma Luhur mengingat setiap kampus punya budaya dan karakteristik yang berbeda. Penelitian ini menitikberatkan pada bagaimana menentukan faktor - faktor yang benar - benar tepat, adil, dan akurat untuk menilai sebuah karya ilmiah yang dihasilkan di lingkungan kampus STMIK Atma Luhur apakah hasil plagiat atau tidak. Tujuan penelitian ini dibuat untuk memudahkan civitas akademika di STMIK Atma Luhur mengenali faktor - faktor yang menjadi sebab munculnya perilaku plagiat dan lalu berusaha menghindarinya. Dengan kata lain mencegah pula pihak kampus menuduh mahasiswa atau dosen melakukan plagiat tanpa dasar penilaian yang tepat, adil, dan akurat. Penelitian ini bermanfaat untuk menjadi salah satu dasar penilaian keaslian hasil karya ilmiah yang dihasilkan di lingkungan STMIK Atma Luhur. Manfaat lainnya, penelitian ini juga memudahkan pimpinan akdemik kampus untuk menyusun penilaian objektif termasuk mengambil keputusan dalam penilaian plagiasi karya ilmiah. 


\section{Tinjauan Pustaka/Penelitian Sebelumnya}

Untuk mampu menilai secara objektif, adil, dan berimbang, maka dalam proses menilai apakah sebuah karya ilmiah yang dihasilkan mengandung unsur plagiat atau tidak, maka perlu mempertimbangkan beberapa aspek penting yang telah diteliti dan dipublikasikan oleh beberapa peneliti lain. Ada beberapa peneliti yang juga tertarik membahas tentang plagiarisme, dan beberapa hasil penelitian tersebut penulis rujuk untuk menjadi referensi dalam penelitian ini.

\subsection{Penelitian Sebelumnya yang Membahas Plagiarisme}

Dasar hukum yang dipakai pihak perguruan tinggi dalam menangani plagiarisme adalah Undang - Undang No. 17 Tahun 2010 tentang pencegahan dan penanggulangan plagiat di perguruan tinggi. Selain mengacu kepada UU No.17 Tahun 2010, ada beberapa penelitian yang juga membahas plagiat seperti penelitian yang dilakukan oleh [5] menyatakan bahwa dengan melakukan pembinaan kepada mahasiswa, dalam hal ini adalah mahasiswa UNY yang akan melakukan tugas akhir, maka tindak plagiasi dapat dicegah. Sedangkan kesimpulan penelitian [6], cara terbaik mendeteksi plagiasi karya ilmiah adalah dengan menggunakan aplikasi. Hasil penelitian [7], pelaku plagiat bervariasi dari mulai dosen, mahasiswa, dan akademisi lainnya, tindakan palgiat tersebut dilakukan baik secara sengaja maupun tidak. Penelitian [8] menyatakan, sering terjadi duplikasi penerbitan makalah. Agar plagiarisme dapat ditekan sejak dini [9], perlunya memasukkan pelatihan penulisan jurnal ilmiah ke dalam kurikulum. Kecenderungan mahasiswa melakukan plagiarisme adalah plagiarisme ide, mengambil teks tanpa mencantumkan sumbernya, dan memparafrasakan tulisan orang lain tanpa mencantumkan sumber aslinya [10]. Dari beberapa hasil penelitian terdahulu, dapat diketahui bahwa plagiarisme dapat dilakukan oleh mahasiswa, atau dosen. Selain itu plagiat juga dapat terjadi karena sengaja ataupun tidak sengaja. Perilaku plagiat juga perlu penanganan serius dari Perguruan Tinggi dengan menjadikan pelatihan penulisan ilmuah sebagai bagian dari kurikulum, serta disarankan pula untuk membangun sebuah mekanisme deteksi plagiat dengan perangkat lunak deteksi kesamaan pola kalimat, sebagai salah satu upaya menekan plagiarisme di Perguruan Tinggi.

\subsection{Penelitian Sebelumnya yang Menggunakan AHP}

Analytical Hierarchy Process (AHP) adalah metode pengambilan keputusan yang diciptakan oleh Thomas L.Saaty pada tahun 1970-an. Saaty mengembangkan metode mengambilan keputusan dengan multi kriteria faktor dan multi kriteria alternatif. Dasar pemikiran memecahkan masalah dengan AHP adalah, menyusun hirarki, menetapkan prioritas, dan menetapkan konsistensi logis. Dengan AHP faktor - faktor yang menjadi pendukung keputusan disusun menjadi hirarki. Penelitian ini menggunakan AHP karena metode ini mempunyai beberapa kelebihan yaitu : mempunyai struktur hirarki, yang disusun dari goal (tujuan), kriteria level 1, level 2, dan seterusnya, sampai sub kriteria paling dalam. Mampu menghitung validitas dengan batas inkonsistensi berbagai kriteria dan alternatif yang dipilih oleh para pakar [11]. Metode AHP menyusun kerangka pengambilan keputusan secara bertingkat mulai dari tujuan, kriteria, dan alternatif yang akan dipilih. Teknik menyusun kerangka pengambilan keputusan tersebut dibuat mengacu kepada [12]. Bentuk kerangka AHP akan tampak seperti Gambar 1 [12].

Prinsip eigen vektor adalah representasi utama yang diperlukan dalam menyusun matriks perbandingan berpasangan. Saat memberikan penilaian numerik, seorang individu mencoba untuk memperkirakan secara berurutan skala rasio yang mendasari dan matriks konsisten setara rasio. Skala perbandingan perbandingan berpasangan dan maknanya yang diperkenalkan oleh Saaty bisa dilihat di bawah ini. Intensitas Kepentingan [13]. Pembobotan kriteria pada setiap tingkat dilakukan dengan membandingkannya berdasarkan kepentingan relatif kriteria menggunakan skala Saaty seperti [14] (lihat Tabel 1). 


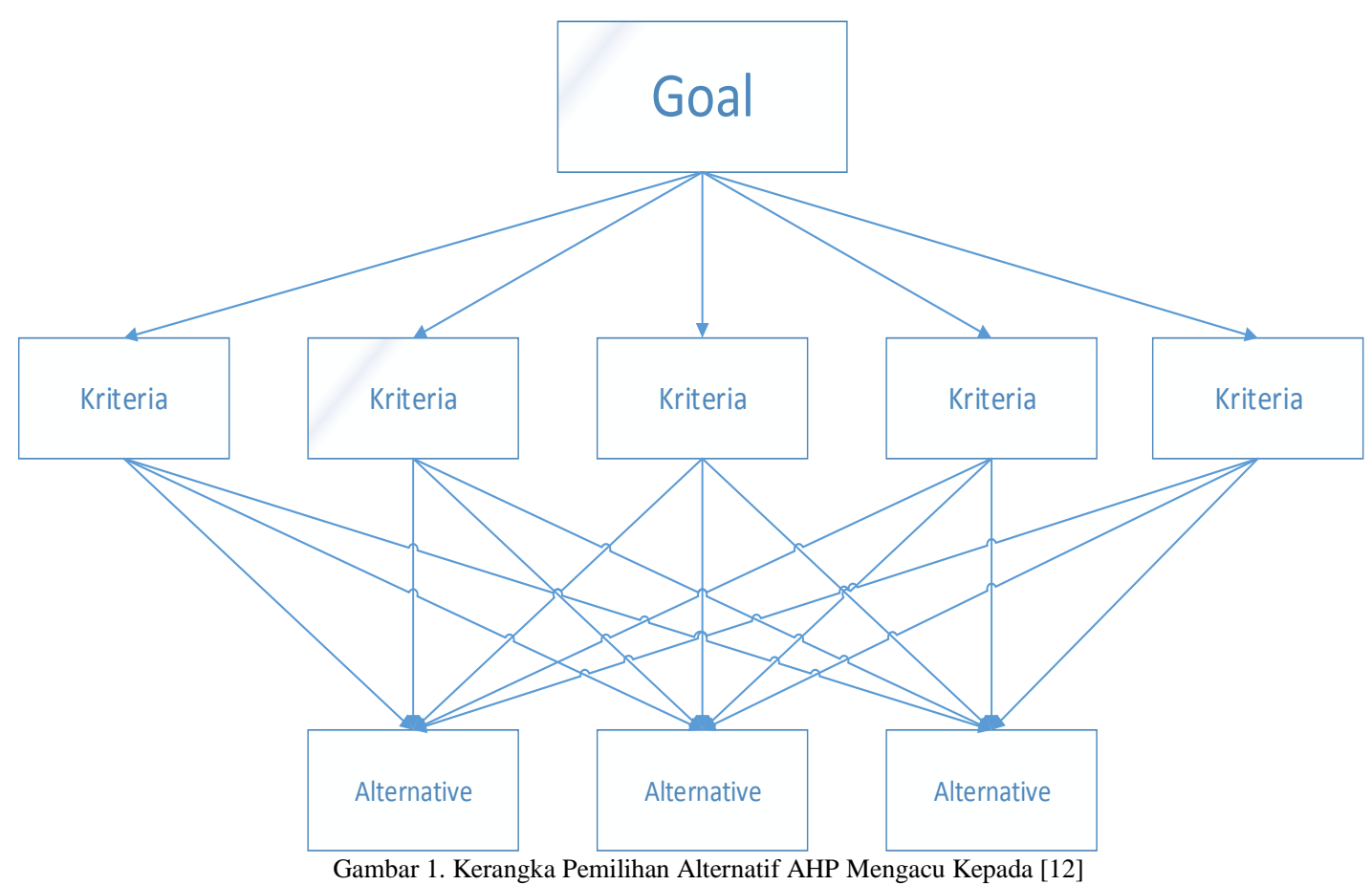

Tabel 1. Level Kepentingan Dalam Matriks Perbandingan Berpasangan Mengacu Kepada [14]

\section{Level}

Arti

Berikut ini adalah beberapa penelitian yang menggunakan AHP dalam pengambilan keputusan, yaitu seperti yang dilakukan oleh [15] menggunakan AHP untuk menemukan komposisi variabel yang paling efektif untuk perkerasan beton. AHP juga digunakan untuk mendiagnosis masalah sistem yang kompleks [16]. AHP sebagai strategi mengoptimalkan dan memprioritaskan perlindungan pesisir untuk Negara Kuwait [17]. Selain itu metode AHP juga digunakan dalam pengambilan keputusan pemilihan galangan untuk membangun kapal tanker di Pulau Batam [18]. Pendekatan AHP digunakan untuk memilih mahasiswa yang akan mendapatkan penghargaan yang proses pemilihannya dilakukan dalam beberapa putaran [19]. 


\subsection{Penelitian Sebelumnya yang Menggunakan Perangkat Lunak Expert Choice 2000}

Expert Choice 2000 adalah perangkat lunak yang didesain khusus untuk mendukung implementasi AHP [20]. Perhitungan matriks perbandingan berpasangan yang menjadi dasar perhitungan antar dua kriteria dalam AHP ditransformasikan menjadi perangkat lunak yang mudah digunakan. Expert Choice 2000 dikembangkan selaras dengan AHP, sehingga input yang berasal dari para pakar dapat dimasukkan ke dalam Expert Choice dan perangkat lunak ini akan mengkalkulasinya berdasarkan prinsip - prinsip yang ada dalam AHP. Umumnya Expert Choice 2000 dipakai sebagai perangkat lunak pendukung kalkulasi AHP. Berikut ini adalah beberapa penelitian yang menggunakan AHP dan Expert Choice sebagai perangkat lunak pendukungnya: AHP dan Expert Choice untuk mengukur perilaku manajemen pengetahuan untuk siswa SD [21]. AHP digunakan untuk memilih metode yang tepat untuk peletakan pipa trenchless di Kroasia [22]. Analytical Hierarchy Process (AHP) yang diimplementasikan dalam paket perangkat lunak Expert Choice [23]. AHP dan Expert Choice untuk memilih sistem ERP (Enterprise Resource Planning) [24]. AHP dan Expert Choice digunakan untuk memilih konsep desain bumber mobil [25]. AHP digunakan untuk membahas analisa efek dari pengambilan keputusan dalam grup untuk menentukan pengembangan produk baru [26]. AHP sebagai Multi Criteria Decision Making (MCDM) dalam membuat analisa perbandingan heterogen untuk menentukan prioritas kriteria dan sub kriterianya secara simultan dalam situasi yang kompleks [27]. AHP dan Expert Choice untuk pemilihan server side scripting untuk sistem informasi sekolah dengan membandingkan ASP, JSP, PHP, PHYTON, dan Ruby [28]. AHP sebagai metode analisa terhadap keamanan turis di China [29]. AHP dan Expert Choice sebagai metode evaluasi arsitektur perangkat lunak [30]. Berdasarkan beberapa penelitian yang menggunakan AHP sebagai metode pengambilan keputusan dengan multi kriteria faktor dan Expert Choice 2000 sebagai perangkat lunak pendukungnya, menunjukkan bahwa kobinasi AHP dan Expert Choice 2000 mampu memberikan hasil yang sesuai dengan kebutuhan penelitian dan dapat mendukung proses pengambilan keputusan dengan informasi yang akurat.

\section{Metodologi}

Studi kasus kualitatif ini dilaksanakan dengan memanfaatkan metode analisis AHP seperti yang dilakukan oleh [12]. AHP adalah metode penelitian yang mampu menggabungkan penelitan kualitatif dan kuantitatif [14]. Dalam penelitian kualitatif dengan AHP maka ada beberapa langkah yang harus dijalankan yaitu: merumuskan masalah, studi literature yang berisi mempelajari metode AHP dan mempelajari kriteria dalam kajian faktor - faktor penyebab plagiat di Perguruan Tinggi, selanjutnya adalah pengumpulan data yang terdiri dari tahap eksplorasi data dan penyebaran kuesioner. Setelah data terkumpul, tahap penelitian berikutnya adalah menentukan alternative bentuk karya ilmiah yang paling sering dijadikan sararan plagiat di Perguruan Tinggi. Setelah alternative didapat, tahap selanjutnya adalah menggunakan AHP dalam menentukan kriteria kualitatif dalam mengkaji faktor - faktor penyebab plagiat di Perguruan Tinggi, selanjutnya adalah mengolah data kualitatif dengan AHP. Lokasi penelitian STMIK Atma Luhur Pangkalpinang. Penentuan lokasi dilakukan dengan sengaja (purposive), dengan pertimbangan bahwa STMIK Atma Luhur adalah kampus tempat penulis mengabdi, sehingga kriteria - kriteria yang disusun dalam hirarki analitik-nya mengandung beberapa poin yang khusus ada di STMIK Atma Luhur. Pertimbangan lainnya adalah, adanya kejadian plagiat yang terjadi di lingkungan kampus di Provinsi Bangka Belitung, baik yang terekspos media maupun tidak. Bentuk penelitian kuantitatif dalam penelitian ini menggunakan data primer dan sekunder. Data primer yang digunakan adalah data yang diperoleh dari responden ahli / pakar yang diperoleh penulis dari hasil wawancara dan isian kuesioner. Responden ahli yang terlibat dalam penelitian ini adalah beberapa orang pakar yang mengetahui secara mendalam tentang faktor - faktor dalam menilai hasil karya ilmiah yang mengandung konten plagiat, khususnya hasil penelitian yang dihasilkan di Perguruan Tinggi. Sedangkan data sekunder didapat dari studi kepustakaan/literature yang membahas masalah plagiarisme di perguruan tinggi. Gambar 2 adalah flowchart yang menggambarkan alur penelitian dengan metode AHP. 
Tahap Awal Penelitian

Merumuskan Faktor - Faktor Penyebab Plagiat di Perguruan Tinggi

\section{Studi Literatur}

1. Melakukan Studi Pustaka terhadap Penelitian terdahulu yang mempunyai tema serupa

2. Merumuskan Kriteria Penyebab Plagiat di Perguruan Tinggi

3. Menentukan Faktor - Faktor Penyebab Plagiat

4. Menentukan Alternatif Bentuk Penelitian dengan hasil plagiat

\section{Pengumpulan Data}

1. Melakukan wawancara dengan responden ahli

2. Memberikan Kuesioner untuk responden ahli.

\section{Penentuan Metode Penelitian}

1. Menggunakan AHP sebagai metode penelitian campuran kualitatif dan kuantitatif

2. Menggunakan Expert Choice sebagai tools.

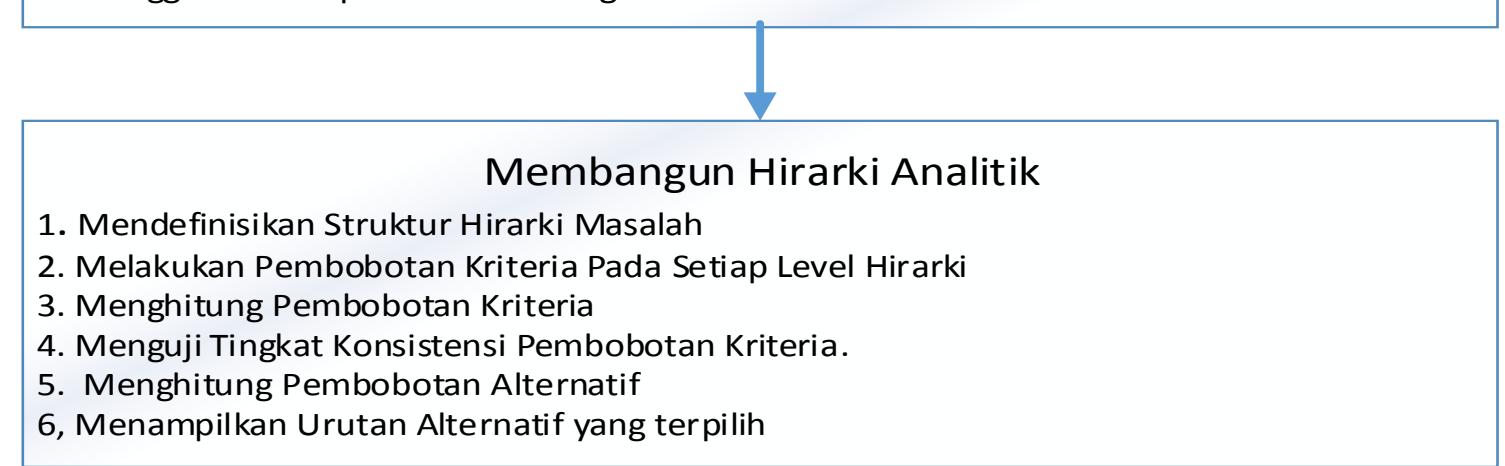

Gambar 2 Alur Penelitian

\section{Hasil dan Pembahasan}

Hasil penelitian ini akan ditampilkan dalam bentuk peringkat / perangkingan kriteria - kriteria yang ada dalam hirarki serta peringkat alternatif apa yang terpilih yang diandai dengan besarnya bobot yang didapat. Gambar 3 adalah solusi yang dihasilkan yang disajikan dalam bentuk hirarki yang sama, namun telah dilengkapi dengan perhitungan dengan Expert Choice 2000.

Pada Gambar 3 terlihat secara hirarkis tujuan, kriteria level 1, kriteria level 2, dan beberapa alternatif yang tersedia. Hasil olahan dengan Expert Choice 2000 dimasukkan kedalam kerangka pemilihan alternatif yang telah disusun dengan prinsip AHP. Tabel hasil dari matriks perbandingan berpasangan ditampilkan pada Tabel 2. 

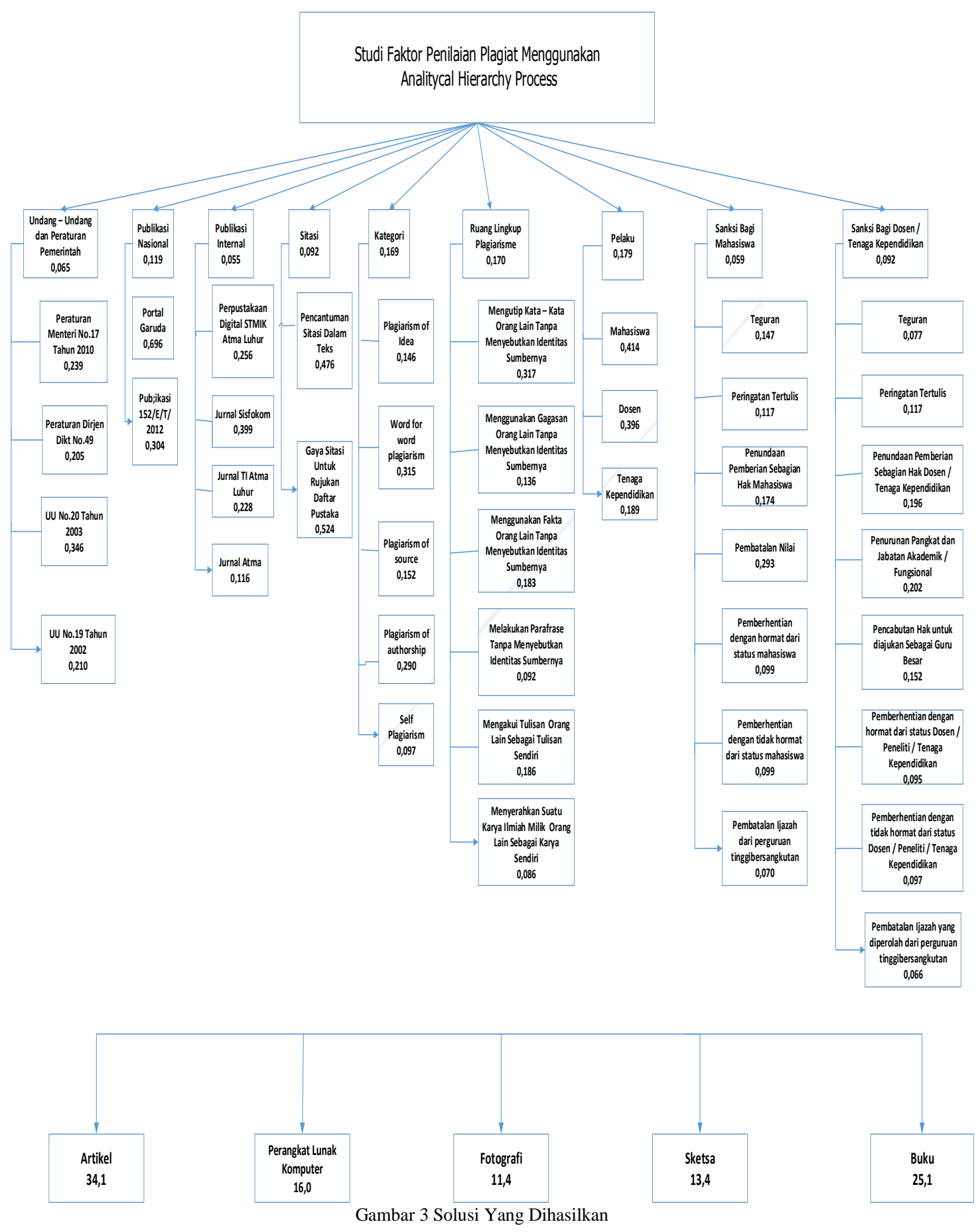

Dari hasil consistensi ratio perhitungan matriks perbandingan berpasangan terlihat bahwa informasi yang diberikan responden ahli untuk penelitian ini mempunyai nilai yang valid. Dengan demikian hasil perhitungan geometrik gabungan data responden ahli cukup konsisten. 
Tabel 2. Tabel Konsistensi Rasio

\begin{tabular}{|c|c|c|}
\hline No & Matriks Perbandingan Berpasangan & $\mathbf{C R}$ \\
\hline 1. & $\begin{array}{l}\text { Perbandingan elemen kriteria level I berdasarkan sasaran Kajian Faktor - Faktor Penilaian Plagiat di } \\
\text { Perguruan Tinggi (Studi Kasus STMIK Atma Luhur) }\end{array}$ & 0,02 \\
\hline 2. & Perbandingan Elemen Sub Kriteria Level II Kriteria Undang - Undang dan Peraturan Pemerintah & 0,03 \\
\hline 3. & Perbandingan Elemen Sub Kriteria Level II Kriteria Publikasi Nasional & 0,00 \\
\hline 4. & Perbandingan Elemen Sub Kriteria Level II Kriteria Publikasi Internal & 0,02 \\
\hline 5. & Perbandingan Elemen Sub Kriteria Level II Kriteria Sitasi & 0,00 \\
\hline 6. & Perbandingan Elemen Sub Kriteria Level II Kriteria Kategori & 0,02 \\
\hline 7. & Perbandingan Elemen Sub Kriteria Level II Kriteria Ruang Lingkup Plagiarisme & 0,03 \\
\hline 8. & Perbandingan Elemen Sub Kriteria Level II Kriteria Pelaku & 0,00 \\
\hline 9. & Perbandingan Elemen Sub Kriteria Level II Kriteria Sanksi Bagi Mahasiswa & 0,03 \\
\hline 10. & Perbandingan Elemen Sub Kriteria Level II Kriteria Sanksi Bagi Dosen & 0,01 \\
\hline 11. & $\begin{array}{l}\text { Perbandingan Elemen Alternatif Level III Kriteria Undang - Undang dan Peraturan Pemerintah sub } \\
\text { kriteria Undang - Undang No. } 20 \text { Tahun } 2010\end{array}$ & 0,02 \\
\hline 12. & $\begin{array}{l}\text { Perbandingan Elemen Alternatif Level III Kriteria Undang - Undang dan Peraturan Pemerintah sub } \\
\text { kriteria Peraturan Menteri No. } 17 \text { tahun }\end{array}$ & 0,01 \\
\hline 13. & $\begin{array}{l}\text { Perbandingan Elemen Alternatif Level III Kriteria Undang - Undang dan Peraturan Pemerintah sub } \\
\text { kriteria Undang - Undang No.19 Tahun } 2002\end{array}$ & 0,02 \\
\hline 14. & $\begin{array}{l}\text { Perbandingan Elemen Alternatif Level III Kriteria Undang - Undang dan Peraturan Pemerintah sub } \\
\text { kriteria Peraturan Dirjen Dikti No. } 49\end{array}$ & 0,02 \\
\hline 15. & Perbandingan Elemen Alternatif Level III Kriteria Publikasi Nasional Sub Kriteria Poral Garuda & 0,01 \\
\hline 16. & $\begin{array}{l}\text { Perbandingan Elemen Alternatif Level III Kriteria Publikasi Nasional Sub Kriteria Pubiikasi } 152 \text { / E / } \\
\text { T /2012 }\end{array}$ & 0,01 \\
\hline 17. & $\begin{array}{l}\text { Perbandingan Elemen Alternatif Level III Kriteria Publikasi Internal Sub Kriteria Perpustakaan Digital } \\
\text { STMIK Atma Luhur }\end{array}$ & 0,02 \\
\hline 18. & Perbandingan Elemen Alternatif Level III Kriteria Publikasi Internal Sub Kriteria Jurnal Sisfokom & 0,01 \\
\hline 19. & $\begin{array}{l}\text { Perbandingan Elemen Alternatif Level III Kriteria Publikasi Internal Sub Kriteria Jurnal TI Atma } \\
\text { Luhur }\end{array}$ & 0,02 \\
\hline 20. & Perbandingan Elemen Alternatif Level III Kriteria Publikasi Internal Sub Kriteria Jurnal Atma & 0,01 \\
\hline 21. & $\begin{array}{l}\text { Perbandingan Elemen Alternatif Level III Kriteria Sitasi Sub Kriteria Pencantuman Sitasi Dalam } \\
\text { Rujukan Daftar Pustaka }\end{array}$ & 0,01 \\
\hline 22. & $\begin{array}{l}\text { Perbandingan Elemen Alternatif Level III Kriteria Sitasi Sub Kriteria Gaya Sitasi Untuk Rujukan } \\
\text { Daftar Pustaka }\end{array}$ & 0,02 \\
\hline 23. & Perbandingan Elemen Alternatif Level III Kriteria Kategori Sub Kriteria Plagiarism of idea & 0,02 \\
\hline 24. & Perbandingan Elemen Alternatif Level III Kriteria Kategori Sub Kriteria word for word plagiarism & 0,03 \\
\hline 25. & Perbandingan Elemen Alternatif Level III Kriteria Kategori Sub Kriteria Plagiarism of source & 0,01 \\
\hline 26. & Perbandingan Elemen Alternatif Level III Kriteria Kategori Sub Kriteria Plagiarism of authorship & 0,00 \\
\hline 27. & Perbandingan Elemen Alternatif Level III Kriteria Kategori Sub Kriteria Self Plagiarism & 0,00 \\
\hline 28. & $\begin{array}{l}\text { Perbandingan Elemen Alternatif Level III Kriteria Ruang Lingkup Plagiarisme Sub Kriteria mengutip } \\
\text { kata - kata orang lain tanpa menyebutkan sumber aslinya. }\end{array}$ & 0,03 \\
\hline 29. & $\begin{array}{l}\text { Perbandingan Elemen Alternatif Level III Kriteria Ruang Lingkup Plagiarisme Sub Kriteria } \\
\text { menggunakan gagasan orang lain tanpa menyebutkan sumber aslinya. }\end{array}$ & 0,00 \\
\hline 30. & Perbandingan Elemen Alternatif Level III Kriteria Ruang Lingkup Plagiarisme Sub Kriteria & 0,04 \\
\hline
\end{tabular}




\begin{tabular}{|c|c|c|}
\hline No & Matriks Perbandingan Berpasangan & CR \\
\hline & menggunakan fakta orang lain tanpa menyebutkan sumber aslinya. & \\
\hline 31. & $\begin{array}{l}\text { Perbandingan Elemen Alternatif Level III Kriteria Ruang Lingkup Plagiarisme Sub Kriteria melakukan } \\
\text { parafrase tanpa menyebutkan sumber aslinya. }\end{array}$ & 0,02 \\
\hline 32. & $\begin{array}{l}\text { Perbandingan Elemen Alternatif Level III Kriteria Ruang Lingkup Plagiarisme Sub Kriteria mengakui } \\
\text { tulisan orang lain sebagai tulisan atau karya ilmiah sendiri. }\end{array}$ & 0,01 \\
\hline 33. & $\begin{array}{l}\text { Perbandingan Elemen Alternatif Level III Kriteria Ruang Lingkup Plagiarisme Sub Kriteria } \\
\text { menyerahkan suatu karya ilmiah dan mengakuinya sebagai karya sendiri. }\end{array}$ & 0,01 \\
\hline 34. & Perbandingan Elemen Alternatif Level III Kriteria Pelaku Sub Kriteria Mahasiswa & 0,03 \\
\hline 35. & Perbandingan Elemen Alternatif Level III Kriteria Pelaku Sub Kriteria Dosen & 0,02 \\
\hline 36. & Perbandingan Elemen Alternatif Level III Kriteria Pelaku Sub Kriteria Tenaga Kependidikan & 0,03 \\
\hline 37. & Perbandingan Elemen Alternatif Level III Kriteria Sanksi Bagi Mahasiswa Sub Kriteria Teguran & 0,02 \\
\hline 38. & $\begin{array}{l}\text { Perbandingan Elemen Alternatif Level III Kriteria Sanksi Bagi Mahasiswa Sub Kriteria Peringatan } \\
\text { Tertulis }\end{array}$ & 0,05 \\
\hline 39. & $\begin{array}{l}\text { Perbandingan Elemen Alternatif Level III Kriteria Sanksi Bagi Mahasiswa Sub Kriteria Penundaan } \\
\text { Sebagian Terhadap Hak Mahasiswa }\end{array}$ & 0,03 \\
\hline 40. & $\begin{array}{l}\text { Perbandingan Elemen Alternatif Level III Kriteria Sanksi Bagi Mahasiswa Sub Kriteria Pembatalan } \\
\text { Nilai }\end{array}$ & 0,02 \\
\hline 41. & $\begin{array}{l}\text { Perbandingan Elemen Alternatif Level III Kriteria Sanksi Bagi Mahasiswa Sub Kriteria Pemberhentian } \\
\text { dengan hormat dari status mahasiswa }\end{array}$ & 0,03 \\
\hline 42. & $\begin{array}{l}\text { Perbandingan Elemen Alternatif Level III Kriteria Sanksi Bagi Mahasiswa Sub Kriteria Pemberhentian } \\
\text { dengan tidak hormat dari status mahasiswa }\end{array}$ & 0,04 \\
\hline 43. & $\begin{array}{l}\text { Perbandingan Elemen Alternatif Level III Kriteria Sanksi Bagi Mahasiswa Sub Kriteria Pembatalan } \\
\text { Ijazah dari perguruan tinggi yang bersangkutan }\end{array}$ & 0,04 \\
\hline 44. & Perbandingan Elemen Alternatif Level III Kriteria Sanksi Bagi Dosen Sub Kriteria Teguran & 0,03 \\
\hline 45. & Perbandingan Elemen Alternatif Level III Kriteria Sanksi Bagi Dosen Sub Kriteria Peringatan Tertulis & 0,02 \\
\hline 46. & $\begin{array}{l}\text { Perbandingan Elemen Alternatif Level III Kriteria Sanksi Bagi Dosen Sub Kriteria Penundaan } \\
\text { Pemberian Hak terhadap dosen }\end{array}$ & 0,04 \\
\hline 47. & $\begin{array}{l}\text { Perbandingan Elemen Alternatif Level III Kriteria Sanksi Bagi Dosen Sub Kriteria Penurunan Pangkat } \\
\text { dan Jabatan Akademik/Fungsional }\end{array}$ & 0,04 \\
\hline 48 & $\begin{array}{l}\text { Perbandingan Elemen Alternatif Level III Kriteria Sanksi Bagi Dosen Sub Kriteria Pencabutan hak } \\
\text { untuk diusulkan menjadi Guru Besar }\end{array}$ & 0,02 \\
\hline 49. & $\begin{array}{l}\text { Perbandingan Elemen Alternatif Level III Kriteria Sanksi Bagi Dosen Sub Kriteria Pemberhentian } \\
\text { dengan hormat dari status dosen }\end{array}$ & 0,02 \\
\hline 50. & $\begin{array}{l}\text { Perbandingan Elemen Alternatif Level III Kriteria Sanksi Bagi Dosen Sub Kriteria Pemberhentian } \\
\text { dengan tidak hormat dari status dosen }\end{array}$ & 0,03 \\
\hline 51. & $\begin{array}{l}\text { Perbandingan Elemen Alternatif Level III Kriteria Sanksi Bagi Dosen Sub Kriteria Pembatalan ijazah } \\
\text { yang diperoleh dari perguruan tinggi yang bersangkutan }\end{array}$ & 0,02 \\
\hline
\end{tabular}

Berikut ini adalah beberapa hasil pengolahan data yang disajikan spesifik untuk tiap kriteria level 1 lengkap dengan bobot tiap sub kriteria di bawahnya dan juga alternatifnya. Pada Gambar 4 disajikan geometrik gabungan untuk kriteria level 1 beserta bobotnya dan alternatif yang diberikan beserta bobotnya. Hasil pengolahan data dengan Expert Choice yang disajikan dalam bentuk pohon (Treeview) menunjukkan bahwa Pelaku adalah faktor penilaian yang paling penting dengan bobot 0,179 dan artikel adalah alternatif yang paling tinggi persentasenya, yaitu mencapai 0,341. Bobot Kriteria keseluruhan sama dengan $100 \%$. Pada hirarki anallitik ini mempunyai sembilan kriteria level 1 yaitu Undang - Undang dan 
Peraturan Pemerintah, Publikasi Nasional, Publikasi Internal, Sitasi, Kategori, Ruang Lingkup Plagiarisme, Pelaku, Sanksi Bagi Mahasiswa, dan Sanksi Bagi Dosen/Tenaga Kependidikan. Hasil yang ada pada Gambar 4 menunjukkan dari $100 \%$ bobot kesembilan kriteria, maka Kriteria Pelaku adalah yang tertinggi yaitu 0,179 atau sama dengan $17,9 \%$. Sedangkan total seluruh altenatif juga $100 \%$. Pada hirarki analitik ini terdapat lima alterntif yang terdiri dari artikel, perangkat lunak komputer, fotografi, sketsa, dan buku. Hasil perhitungan pada Gambar 4 menunjukkan bahwa alternatif artikel adalah yang tertinggi bobotnya mencapai 0,341 atau $34,1 \%$.

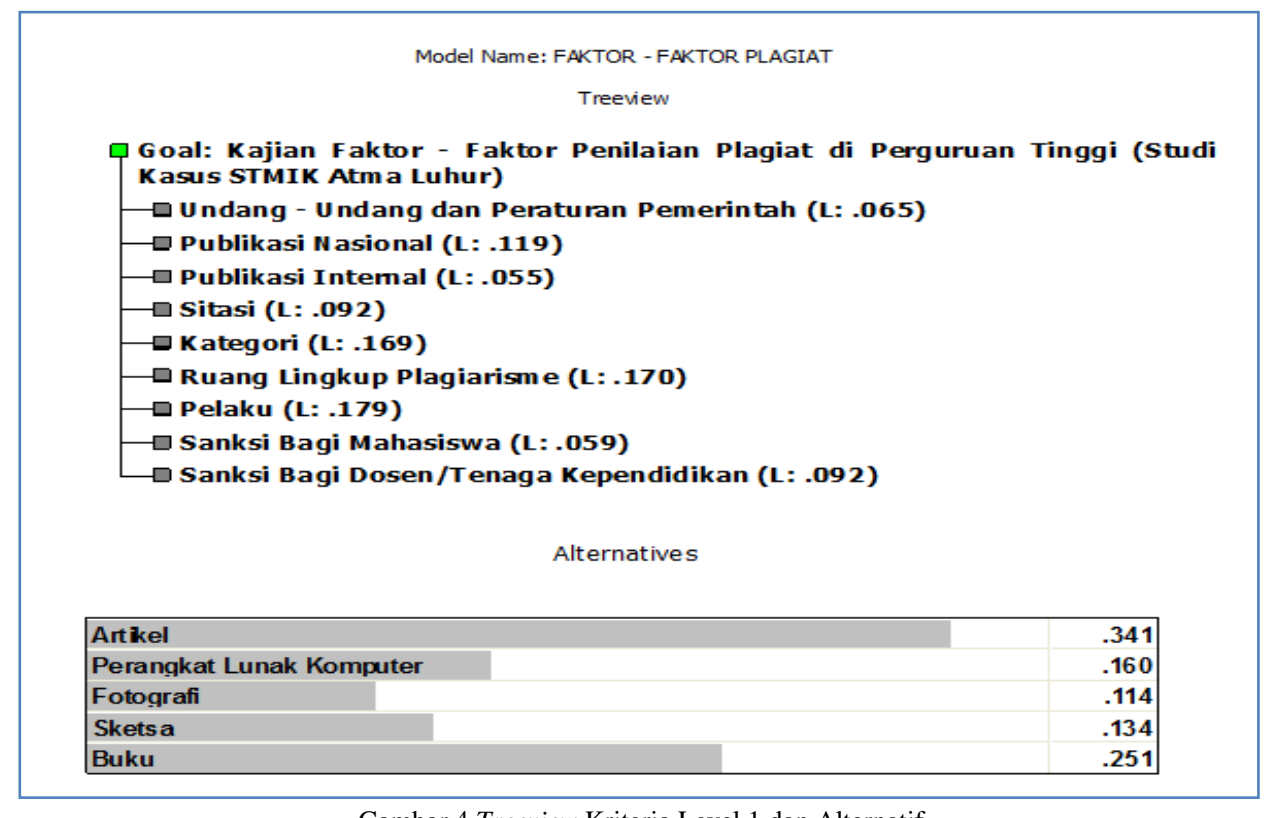

Gambar 4 Treeview Kriteria Level 1 dan Alternatif

Gambar 5 menunjukkan alternatif yang terpilih secara keseluruhan. Berdasarkan Synthesis Summary hasil pengolahan data dengan Expert Choice menunjukkan bahwa Artikel adalah bentuk plagiat yang paling banyak terjadi dengan bobot mencapai $34,1 \%$.

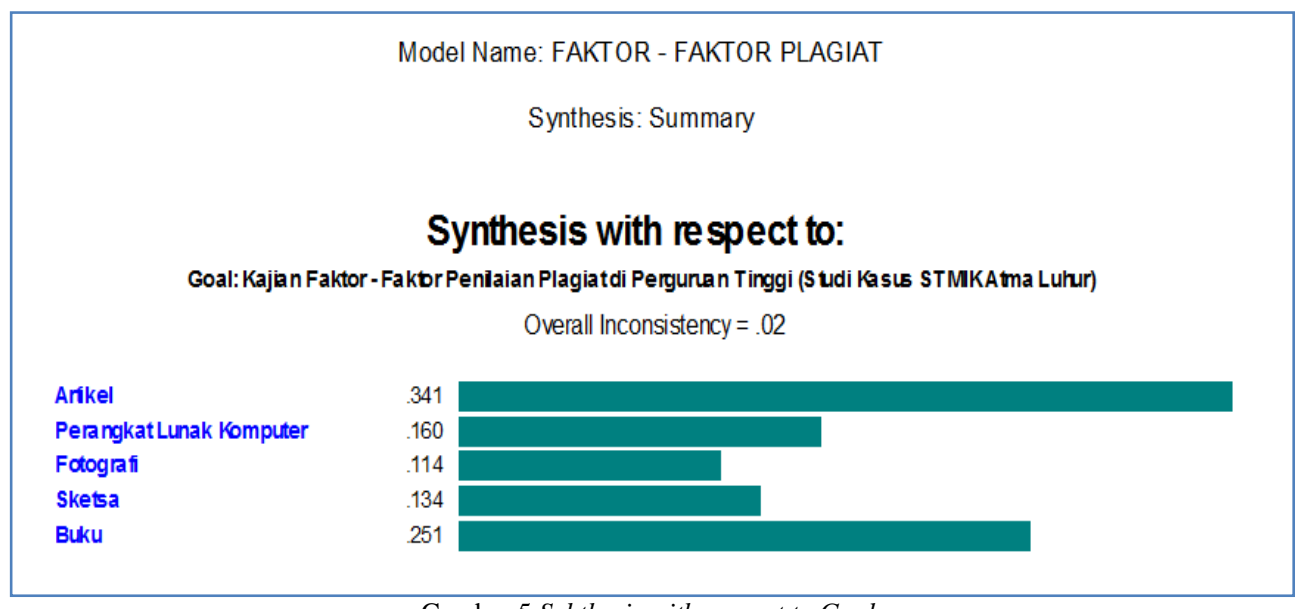

Gambar 5 Sybthesis with respect to Goal

Gambar 6 adalah Dinamic Sentivity for nodes below. Gambar ini menunjukkan bobot dalam persentase untuk tiap kriteria level 1 dan alternatif secara bersampingan (side by side). 


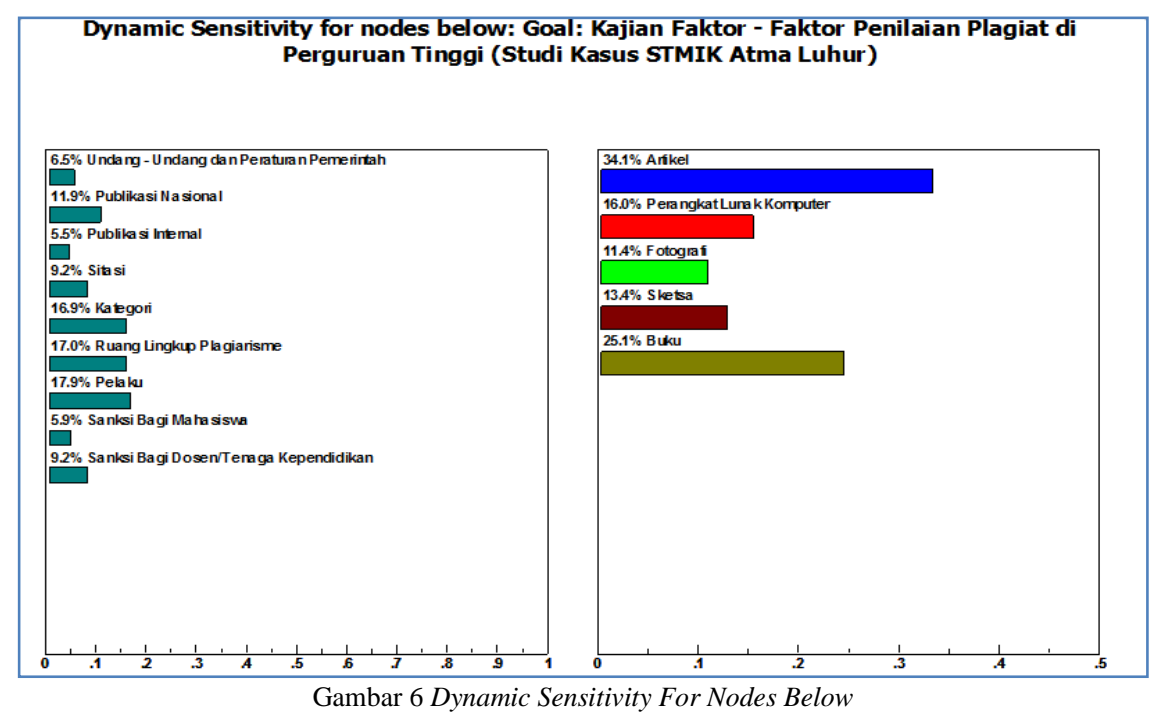

Menurut [31], AHP mampu memberikan hasil alternatif terbaik dengan menampilkannya secara keseluruhan dalam sebuah tabel. Pada Tabel 3, semua level atribut ditampilkan secara lengkap dengan hasil perhitungan pair wise comparison matrix $\left(P R \_W T\right)$ serta hasil presentase tiap - tiap alternatif yang disajikan secara horizontal. Dengan sajian tabel maka pengambil keputusan bisa melihat secara lengkap dan rinci semua faktor pendukung pengambilan keputusan. Selain itu tampilan tabel juga memeriksa tingkat CR tiap - tiap sub kriteria pada tiap alternatifnya untuk tetap memastikan bahwa hasil perhitungan tetap valid dan konsisten.

Tabel 3 Peringkat Komposit Untuk Teknik AHP

\begin{tabular}{|c|c|c|c|c|c|c|c|c|c|c|}
\hline $\begin{array}{l}\mathbf{N} \\
\mathbf{o .}\end{array}$ & Attributes & $\begin{array}{l}\text { PR_W } \\
\text { T }\end{array}$ & Sub_Attributes & PR_WT & Artikel & $\begin{array}{l}\text { Perang } \\
\text { kat } \\
\text { Lunak }\end{array}$ & $\begin{array}{l}\text { Fotograf } \\
\text { i }\end{array}$ & Sketsa & Buku & CR \\
\hline \multirow[t]{4}{*}{1.} & \multirow[t]{4}{*}{ UU \& PP } & \multirow[t]{4}{*}{0,065} & $\begin{array}{l}\text { Peraturan Menteri } \\
\text { No.17 } 2010\end{array}$ & 0,239 & 0,342 & 0,65 & 0,105 & 0,133 & 0,255 & 0,01 \\
\hline & & & $\begin{array}{l}\text { Peraturan Dirjen } \\
\text { Dikti No.49 }\end{array}$ & 0,205 & 0,349 & 0,136 & 0,114 & 0,120 & 0,282 & 0,02 \\
\hline & & & $\begin{array}{l}\text { UU No.20 Tahun } \\
2003\end{array}$ & 0,346 & 0,307 & 0,153 & 0,105 & 0,115 & 0,319 & 0,02 \\
\hline & & & $\begin{array}{l}\text { UU No. } 19 \text { Tahun } \\
2002\end{array}$ & 0,210 & 0,313 & 0,155 & 0,114 & 0,128 & 0,289 & 0,02 \\
\hline \multirow[t]{2}{*}{2} & \multirow{2}{*}{$\begin{array}{l}\text { Publikasi } \\
\text { Nasional }\end{array}$} & \multirow[t]{2}{*}{0,119} & Portal Garuda & 0,696 & 0,424 & 0,130 & 0,106 & 0,104 & 0,236 & 0,01 \\
\hline & & & $\begin{array}{l}\text { Publikasi } \\
\text { 152/E/T/2012 }\end{array}$ & 0,304 & 0,357 & 0,128 & 0,119 & 0,119 & 0,278 & 0,01 \\
\hline \multirow[t]{4}{*}{3.} & \multirow[t]{4}{*}{$\begin{array}{l}\text { Publikasi } \\
\text { Internal }\end{array}$} & \multirow[t]{4}{*}{0,055} & $\begin{array}{l}\text { Perpustakaan } \\
\text { Digital STMIK } \\
\text { Atma Luhur }\end{array}$ & 0,256 & 0,363 & 0,143 & 0,124 & 0,207 & 0,163 & 0,02 \\
\hline & & & Jurnal Sisfokom & 0,399 & 0,419 & 0,137 & 0,120 & 0,186 & 0,137 & 0,01 \\
\hline & & & $\begin{array}{l}\text { Jurnal TI Atma } \\
\text { Luhu }\end{array}$ & 0,228 & 0,358 & 0,212 & 0,135 & 0,174 & 0,122 & 0,02 \\
\hline & & & Jurnal Atma & 0,116 & 0,377 & 0,193 & 0,131 & 0,161 & 0,137 & 0,01 \\
\hline
\end{tabular}




\begin{tabular}{|c|c|c|c|c|c|c|c|c|c|c|}
\hline $\begin{array}{l}\mathbf{N} \\
\mathbf{o .}\end{array}$ & Attributes & $\begin{array}{l}\text { PR_W } \\
\text { T }\end{array}$ & Sub_Attributes & PR_WT & Artikel & $\begin{array}{l}\text { Perang } \\
\text { kat } \\
\text { Lunak }\end{array}$ & $\begin{array}{l}\text { Fotograf } \\
\text { i }\end{array}$ & Sketsa & Buku & $\mathbf{C R}$ \\
\hline \multirow[t]{2}{*}{4.} & \multirow[t]{2}{*}{ Sitasi } & \multirow[t]{2}{*}{0,092} & $\begin{array}{l}\text { Pencantuman } \\
\text { Sitasi Dalam Teks }\end{array}$ & 0,476 & 0,324 & 0,091 & 0,110 & 0,134 & 0,341 & 0,01 \\
\hline & & & $\begin{array}{l}\text { Gaya Sitasi Untuk } \\
\text { Rujukan Daftar } \\
\text { Pustaka }\end{array}$ & 0,524 & 0,330 & 0,085 & 0,133 & 0,140 & 0,311 & 0,02 \\
\hline \multirow[t]{5}{*}{5.} & \multirow[t]{5}{*}{ Kategori } & \multirow[t]{5}{*}{0,169} & $\begin{array}{l}\text { Word for word } \\
\text { plagiarism }\end{array}$ & 0,315 & 0,319 & 0,170 & 0,100 & 0,101 & 0,310 & 0,03 \\
\hline & & & $\begin{array}{l}\text { Plagiarism of } \\
\text { authorship }\end{array}$ & 0,290 & 0,332 & 0,157 & 0,108 & 0,109 & 0,294 & 0,00 \\
\hline & & & $\begin{array}{l}\text { Plagiarism of } \\
\text { source }\end{array}$ & 0,152 & 0,227 & 0,223 & 0,106 & 0,112 & 0,331 & 0,01 \\
\hline & & & Plagiarism of idea & 0,146 & 0,247 & 0,229 & 0,121 & 0,130 & 0,273 & 0,02 \\
\hline & & & Self plagiarism & 0,097 & 0,342 & 0,202 & 0,104 & 0,099 & 0,254 & 0,00 \\
\hline \multirow[t]{6}{*}{6.} & \multirow[t]{6}{*}{$\begin{array}{l}\text { Ruang } \\
\text { Lingkup } \\
\text { Plagiarisme }\end{array}$} & \multirow[t]{6}{*}{0,170} & $\begin{array}{l}\text { Mengutip kata - } \\
\text { kata orang lain } \\
\text { tanpa } \\
\text { menyebutkan } \\
\text { identitas } \\
\text { sumbernya }\end{array}$ & 0,317 & 0,365 & 0,152 & 0,099 & 0,103 & 0,281 & 0,03 \\
\hline & & & $\begin{array}{l}\text { Mengutip gagasan } \\
\text { orang lain tanpa } \\
\text { menyebutkan } \\
\text { identitas } \\
\text { sumbernya }\end{array}$ & 0,136 & 0,264 & 0,200 & 0,137 & 0,124 & 0,275 & 0,00 \\
\hline & & & $\begin{array}{l}\text { Mengutip fakta } \\
\text { orang lain tanpa } \\
\text { menyebutkan } \\
\text { identitas } \\
\text { sumbernya }\end{array}$ & 0,183 & 0,347 & 0,154 & 0,104 & 0,106 & 0,290 & 0,04 \\
\hline & & & $\begin{array}{l}\text { Melakukan } \\
\text { parafrase tanpa } \\
\text { menyebutkan } \\
\text { identitas } \\
\text { sumbernya }\end{array}$ & 0,092 & 0,350 & 0,127 & 0,113 & 0,117 & 0,293 & 0,02 \\
\hline & & & $\begin{array}{l}\text { Mengakui tulisan } \\
\text { orang lain sebagai } \\
\text { tulisan sendiri }\end{array}$ & 0,186 & 0,363 & 0,120 & 0,118 & 0,117 & 0,283 & 0,01 \\
\hline & & & $\begin{array}{l}\text { Menyerahkan } \\
\text { suatu karya ilmiah } \\
\text { milik orang lain } \\
\text { sebagai karya } \\
\text { sendiri }\end{array}$ & 0,086 & 0,301 & 0,197 & 0,121 & 0,128 & 0,253 & 0,01 \\
\hline \multirow[t]{3}{*}{7.} & \multirow[t]{3}{*}{ Pelaku } & \multirow[t]{3}{*}{0,179} & Mahasiswa & 0,414 & 0,378 & 0,164 & 0,131 & 0,214 & 0,113 & 0,03 \\
\hline & & & Dosen & 0,396 & 0,345 & 0,184 & 0,111 & 0,101 & 0,260 & 0,02 \\
\hline & & & $\begin{array}{l}\text { Tenaga } \\
\text { Kependidikan }\end{array}$ & 0,189 & 0,365 & 0,185 & 0,132 & 0,173 & 0,145 & 0,03 \\
\hline \multirow[t]{2}{*}{8.} & \multirow{2}{*}{$\begin{array}{l}\text { Sanksi } \\
\text { Bagi } \\
\text { Mahasiswa }\end{array}$} & \multirow[t]{2}{*}{0,059} & Teguran & 0,147 & 0,392 & 0,139 & 0,117 & 0,202 & 0,149 & 0,02 \\
\hline & & & $\begin{array}{l}\text { Peringatan } \\
\text { Tertulis }\end{array}$ & 0,117 & 0,361 & 0,159 & 0,114 & 0,209 & 0,157 & 0,05 \\
\hline
\end{tabular}




\begin{tabular}{|c|c|c|c|c|c|c|c|c|c|c|}
\hline $\begin{array}{l}\mathbf{N} \\
\mathbf{o .}\end{array}$ & Attributes & $\begin{array}{l}\text { PR_W } \\
\text { T }\end{array}$ & Sub_Attributes & PR_WT & Artikel & $\begin{array}{l}\text { Perang } \\
\text { kat } \\
\text { Lunak }\end{array}$ & $\begin{array}{l}\text { Fotograf } \\
\text { i }\end{array}$ & Sketsa & Buku & CR \\
\hline & & & $\begin{array}{ll}\text { Penundaan } & \\
\text { Pemberian } & \\
\text { Terhadap } & \\
\text { Sebagian } & \text { Hak } \\
\text { Mahasiswa } & \end{array}$ & 0,174 & 0,344 & 0,164 & 0,123 & 0,226 & 0,143 & 0,03 \\
\hline & & & Pembatalan Nilai & 0,293 & 0,344 & 0,199 & 0,136 & 0,204 & 0,117 & 0,02 \\
\hline & & & \begin{tabular}{lr}
\multicolumn{2}{l}{ Pemberhentian } \\
Dengan & Hormat \\
dari & Status \\
Mahasiswa
\end{tabular} & 0,099 & 0,344 & 0,165 & 0,123 & 0,239 & 0,128 & 0,03 \\
\hline & & & $\begin{array}{l}\text { Pemberhentian } \\
\text { Dengan Tidak } \\
\text { Hormat dari } \\
\text { Status Mahasiswa }\end{array}$ & 0,099 & 0,344 & 0,179 & 0,115 & 0,227 & 0,136 & 0,04 \\
\hline & & & $\begin{array}{l}\text { Pembatalan Ijazah } \\
\text { dari Perguruan } \\
\text { Tinggi dari } \\
\text { Perguruan Tinggi } \\
\text { Yang } \\
\text { Bersangkutan }\end{array}$ & 0,070 & 0,361 & 0,175 & 0,112 & 0,217 & 0,134 & 0,04 \\
\hline \multirow[t]{8}{*}{9.} & \multirow{8}{*}{$\begin{array}{l}\text { Sanksi } \\
\text { Bagi Dosen } \\
/ \quad \text { Tenaga } \\
\text { Kependidik } \\
\text { an }\end{array}$} & \multirow[t]{8}{*}{0,092} & Teguran & 0,077 & 0,330 & 0,160 & 0,118 & 0,224 & 0,168 & 0,03 \\
\hline & & & $\begin{array}{l}\text { Peringatan } \\
\text { Tertulis }\end{array}$ & 0,117 & 0,325 & 0,175 & 0,101 & 0,151 & 0,249 & 0,02 \\
\hline & & & $\begin{array}{l}\text { Penundaan } \\
\text { Pemberian Hak } \\
\text { Dosen }\end{array}$ & 0,196 & 0,346 & 0,194 & 0,112 & 0,146 & 0,203 & 0,04 \\
\hline & & & $\begin{array}{l}\text { Penurunan } \\
\text { Pangkat / Jabatan } \\
\text { Akademik }\end{array}$ & 0,202 & 0,330 & 0,171 & 0,089 & 0,096 & 0,315 & 0,04 \\
\hline & & & $\begin{array}{lr}\text { Pencabutan } & \text { Hak } \\
\text { Untuk } & \text { Diajukan } \\
\text { Sebagai } & \text { Guru } \\
\text { Besar } & \end{array}$ & 0,152 & 0,314 & 0,192 & 0,107 & 0,110 & 0,277 & 0,02 \\
\hline & & & $\begin{array}{lr}\text { Pemberhentian } \\
\text { Dengan } & \text { Hormat } \\
\text { dari } & \text { Status } \\
\text { Sebagai Dosen }\end{array}$ & 0,095 & 0,270 & 0,194 & 0,099 & 0,123 & 0,315 & 0,02 \\
\hline & & & \begin{tabular}{lr}
\multicolumn{2}{l}{ Pemberhentian } \\
Dengan & Tidak \\
Hormat & dari \\
Status & Sebagai \\
Dosen &
\end{tabular} & 0,097 & 0,326 & 0,170 & 0,094 & 0,123 & 0,287 & 0,03 \\
\hline & & & $\begin{array}{l}\text { Pembatalan Ijazah } \\
\text { yang diperoleh } \\
\text { dari Perguruan } \\
\text { Tinggi Yang } \\
\text { bersangkutan }\end{array}$ & 0,066 & 0,278 & 0,206 & 0,105 & 0,161 & 0,250 & 0,02 \\
\hline
\end{tabular}

Kontribusi dan batasan hasil penelitian ini adalah kemampuan AHP memberikan penilaian gabungan / skor komposit yang mencerminkan prioritas relatif dari semua alternatif yang ada dalam hirarki. Berdasarkan 
tabel 2, maka attribut / kriteria yang paling berpengaruh adalah Pelaku dengan bobot 0,179 atau sama dengan $17,9 \%$.

\section{Kesimpulan}

\subsection{Simpulan}

Plagiarisme adalah perilaku negatif yang merusak nama baik pelakunya dan merugikan pihak yang diambil karya ilmiahnya. Maraknya laku plagiat di Perguruan Tinggi menjadi perhatian dan keprihatinan banyak pihak, terutama pihak Perguruan Tinggi. Merujuk kepada Undang-Undang dan Peraturan Pemerintah yang khusus menangani masalah plagiat di Perguruan Tinggi, maka tiap Perguruan Tinggi berusaha untuk menekan angka plagiarisme dengan berbagai cara, misalnya dengan melakukan pelatihan menulis karya ilmiah, menggunakan perangkat lunak pendeteksi plagiat, dan memberikan sanksi terhadap pelaku plagiat.

AHP adalah salah satu teknik dalam membuat keputusan yang melibatkan masalah multikriteria dan multi alternatif. Semua kriteria dan alternatif yang terlibat dalam pengambilan keputusan disusun secara bertingkat dalam sebuh hirarki. Hirarki tersebut memberikan gambaran faktor yang berbeda untuk menghasilkan metode terbaik pengambilan keputusan.

Hasil dari penelitian ini menunjukkan bahwa sebab plagiat yang paling utama adalah manusia atau pelaku; dan artikel hasil plagiat tersebut paling sering dipublikasikan di jurnal nasional. Hasil penelitian ini masih terbatas pada ruang lingkup kampus STMIK Atma Luhur saja. Dengan mengetahui sebab utama dan hasil penelitian yang paling rentan berasal dari hasil plagiat, maka pihak pimpinan kampus dapat merancang cara atau regulasi yang mencegah atau minimal mengurangi plagiarisme.

\subsection{Saran}

Penelitian ini baru sebatas membuat kajian terhadap faktor-faktor apa saja yang menjadi sebab dan bentuk plagiat di Perguruan Tinggi. Hasil dari penelitian ini menunjukkan beragam faktor yang menjadi pemicu tindak plagiasi dan masalah yang ditimbulkannya. Penelitian ini walaupun mengambil cakupan wilyah yang terbatas, namun dapat mewakili keadaan perguruan tinggi, khususnya dalam hal memahami faktorfaktor penyebab plagiat dan menggunakan informasi tersebut untuk mewaspadai pelaku dan hasil penelitian yang rentan mengandung unsur plagiarisme. Penelitian ini dapat menjadi masukan dan informasi pendukung bagi pimpinan kampus dalam mengambil keputusan terkait plagiarisme hasil penelitian. Dengan memahami pola, bentuk, pelaku, dan cara melakukan plagiat, maka pimpinan dapat dengan bijak memilih strategi apa yang paling sesuai untuk menekan tindak plagiasi di perguruan tinggi, khususnya di STMIK Atma Luhur.

\section{Daftar Rujukan}

[1] Undang-Undang Republik Indonesia Nomor 12 Tahun 2012 Tentang Pendidikan Tinggi, [Online] Available at http://risbang.ristekdikti.go.id/regulasi/uu-12-2012.pdf

[2] Undang - Undang No.17 Tahun 2010 Tentang Pencegahan dan Penanggulangan Plagiat di Perguruan Tinggi, [Online] Available at http://peraturan.go.id/pp/nomor-17-tahun-2010-11e44c4ea9755c808dde313231353436.html

[3] Surat Dirjen DIKTI No. 152/e/t/2012 Tentang Publikasi Karya Ilmiah, [Online] Available at http://luk.staff.ugm.ac.id/atur/SKDirjen152-E-T-2012KaryaIlmiah.pdf

[4] Sederet Kasus Plagiarisme di Kampus, [Online] Available at http://news.okezone.com/read/2014/02/25/373/946214/sederetkasus-plagiarisme-di-kampus

[5] Mulyana. Pencegahan Tindak Plagiarisme Dalam Penulisan Skripsi : Upaya Memperkuat Pembentukan Karakter Di Dunia Akademik, Cakrawala Pendidikan, Mei 2010, Th. XXIX, Edisi Khusus Dies Natalis UNY

[6] Kurniawati, Anna., Sekarwati, K. Ade., Wicaksana, I W. Simri., Arsitektur Untuk Aplikasi Deteksi Kesamaan Dokumen Bahasa Indonesia, Konferensi Nasional Sistem Informasi 2012, STMIK - STIKOM Bali 23-25 Pebruari 2012 
[7] Ernawati, Endang., Anindito., Atmojo., R N P., Sistem Pendeteksi Plagiarisme Untuk Tugas Akhir Mahasiswa Di Universitas Bina Nusantara : Studi Pendahuluan, HUMANIORA Vol.5 No.1 April 2014: 541-549

[8] Marlina, Ekawati., Setiorini, Retno Asihanti., dan Tambunan, Kamariah., Duplikasi Artikel Jurnal Ilmiah Indonesia : Analisis Kualitas, Widyariset Volume 18, Nomor 1, April 2015 115-126

[9] Herqutanto., Plagiarisme, Runtuhnya Tembok Kejujuran Akademik, eJKI Vol. 1, No. 1, April 2013

[10] Hasan, Anisah., Akib, Irwan., Ibrahim, Mas'ud., Fenomena Plagiarisme Mahasiswa, Jurnal Equilibrium Pendidikan Sosiologi FKIP Unismuh Makassar, Volume IV No. 1 Mei 2016

[11] Saaty, TL., The AHP : How to make decision, European Journal of Operational Research 48 (1990) 9-26 North - Holland

[12] Sensuse Indra D, Sari Rahma F, "Penerapan Metode Analytic Hierarchy Process Dalam Sistem Penunjang Keputusan Untuk Pemilihan Asuransi”, Jurnal Sistem Informasi MTI-UI, Volume 4, Nomor 2, ISBN 1412-8896

[13] Saaty, TL., Decision Aiding Decision-Making With The AHP : Why Is The Principal Eigenvector Necessary, European Journal of Operational Research 145 (2003) 85-91

[14] Saaty, Thomas L. dan Michael P. Niemera. 2006. "A Framework for Making a Better Decision: How to Make More Effective Site Selection, Store Closing, and Other Real Estate Decisions”. Research Review, Vol.13, No.1, hal.4.[Online] Available at http://www.who.int/immunization/sage/2 Framework_Better_decision_Saaty.pdf

[15] Ameri, Alireza., Application of the Analytic Hierarchy Process (AHP) for Prioritize of Concrete Pavement, Global Journal of HUMAN SOCIAL SCIENCE Interdisciplinary Volume 13 Issue 3 Version 1.0 Year 2013

[16] Cabala. Pawel., Using The Analytic Hierarchy Process In Evaluating Decision Alternatives, Operations Research and Decisions No.1 2010

[17] S. Baby, AHP Modeling for Multicriteria Decision-Making and to Optimise Strategies for Protecting Coastal Landscape Resources, International Journal of Innovation, Management and Technology, Vol. 4, No. 2, April 2013

[18] Nugroho, Y E., Analytical Hierarchy Process Method In Decision Making Shipyard Election To New Tanker Ship Building In Batam Island, [Online]. Available : http://digilib.its.ac.id/public/ITS-Undergraduate-20624-Paper-1331753.pdf

[19] P. Kousalya, G. Mahender Reddy, S. Supraja, V. Shyam Prasad, Analytical Hierarchy Process approach - An application of engineering education, Mathematica Aeterna, Vol. 2, 2012, no. 10, $861-878$

[20] Ishizaka, Alessio., Labib, Ashraf., Analytic Hierarchy Process and Expert Choice : Benefits and Limitations, ORInsight, 22(4), p. 201-220, 2009

[21] Lee, Chung-Ping., Lou, Shi-Jer., Shih, Ru-Chu., Tseng, Kuo-Hung., An Ahp-Based Weighted Analysis Of Network Knowledge Management Platforms For Elementary School Students, The Turkish Online Journal of Educational Technology October 2011, volume 10 Issue 4

[22] Adamović, Petar., Dunović, Časlav., Nahod, Maja - Marija., Expert Choice Model For Choosing Appropriate Trenchless Method For Pipe Laying, University of Zagreb, Politechnics in Zagreb, Department for Civil Engineering

[23] Ishizaka Alessio and Labib Ashraf, "Analytic Hierarchy Process and Expert Choice: Benefits and Limitations", ORInsight,22(4), $\quad$ p. 201-220, $2009 . \quad$ [Online] Available at https://pdfs.semanticscholar.org/758c/ab67ec9ee55c5d21418e90d12085d9e28b2c.pdf

[24] Alanbay, Oyku., ERP Selection Using Expert Choice Software, ISAHP 2005, Honolulu, Hawaii, July 8-10, 2005

[25] Hambali, A., Sapuan, S M., Ismail, N., Nukman, Y,. Application Of Analytical Hierarchy Process In The Design Concept Selection Of Automotive Composite Bumper Beam During The Conceptual Design Stage, Scientific Research and Essay Vol. 4 (4) pp. 198-211, April, 2009, [Online] Available http://www.academicjournals.org/SRE

[26] Hummel JM, Rossumw Van, Verkerke GJ, Rakhorst G., The Effects Of Team Expert Choice On Group Decision-Making In Collaborative New Product Development, Journal Of Multi-Criteria Decision Analysis, 9(1-3): 90-98 (2000). () John Wiley \& Sons Limited. Reprinted With Permission Of The Publisher

[27] Ghorbannezhad, Payam., Azizi Majid., Ray, Charles., Yoo, Changkyoo., Ramazani, Omid., Application Of Sensitivity Analysis For Assessment Of Energy And Environmental Alternatives In The Manufacture By Using Analytic Hierarchy Process, Environment Protection Engineering Vol. 392013 No. 3 DOI: 10.5277/EPE130301

[28] Mustari, Dewi., Model Pemilihan Server Side Scripting Untuk Sistem Informasi Sekolah: Studi Komparasi ASP, JSP, PHP, PYTHON, dan RUBY, Journal of Information Systems, Volume 11, Issue 1, April 2015

[29] Fan, Guojing., Goodman, Erik D., Liu, Zhijun., AHP (Analytic Hierarchy Process) and Computer Analysis Software Used in Tourism Safety, Journal of Software, Vol. 8, No. 12, December 2013

[30] Zhu, Liming., Aurum, Aybüke., Gorton,Ian., Jeffery, Ross., Trade off and Sensitivity Analysis in Software Architecture Evaluation Using Analytic Hierarchy Process, [Online] Available at http://link.springer.com/article/10.1007\%2Fs11219-005$\underline{4251-0}$

[31] Thampi L, Manickem SM, Kuppuswamy S, Muralidharana C, "Applying Analytic Hierarchy Process (AHP) in the selection of best method for the preparation of solid dispersion as a carrier for the controlled drug delivery of Delayed Release tablets" Scholars Research Library Der Pharmacia Lettre, 2016, 8 (4):315-323 